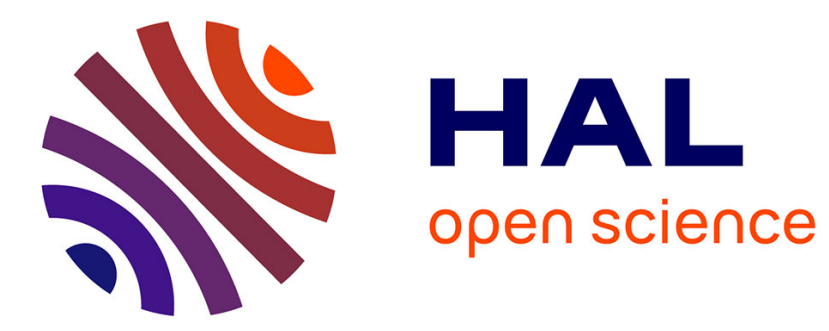

\title{
Towards a reconciling model about the initial peopling of America
}

Stéphane Mazières

\section{To cite this version:}

Stéphane Mazières. Towards a reconciling model about the initial peopling of America. Comptes Rendus Biologies, 2011, 334 (7), pp.497 - 504. 10.1016/j.crvi.2011.03.007 . hal-01820056

\section{HAL Id: hal-01820056 https://hal.science/hal-01820056}

Submitted on 2 Dec 2019

HAL is a multi-disciplinary open access archive for the deposit and dissemination of scientific research documents, whether they are published or not. The documents may come from teaching and research institutions in France or abroad, or from public or private research centers.
L'archive ouverte pluridisciplinaire HAL, est destinée au dépôt et à la diffusion de documents scientifiques de niveau recherche, publiés ou non, émanant des établissements d'enseignement et de recherche français ou étrangers, des laboratoires publics ou privés. 
Towards a reconciling model about the initial peopling of America

Vers un modèle consensus du peuplement initial de l'Amérique

Stéphane Mazières ${ }^{1}$

${ }^{1}$ UMR 6578 Anthropologie bio-culturelle, Université de la Méditerranée-CNRS-EFS, Marseille - FRANCE

KEY WORDS : Amerindian biological variability; discordance; re-assessment; Beringia; peopling models

MOTS CLES : variabilité biologique amérindienne; discordance; réappréciation; Béringie; modèles de peuplement

Correspondence to:

$\underline{\text { stephane.mazieres@univmed.fr }}$

UMR 6578 Anthropologie bio-culturelle,

Université de la Méditerranée-CNRS-EFS

Faculté de Médecine - Secteur Nord - Batiment A - CS80011

Bd Pierre Dramard

13344 MARSEILLE Cedex 15 - France

Tel : 0496152692

Fax : 0491608062 


\section{ABSTRACT}

The last two decades have seen numerous debates in the field of the initial settlement of America and noteworthy was the disagreement between physical and molecular anthropologists. Recently, it has been pointed out that this discordance could partly originate from the description methods and classification labels used in craniometry which did not account fairly for the within-sample and within-group variance. From there, a federative model for the initial peopling of America has been designed which could now explain the biological variability found at both the craniofacial and genetic level. This is a major step in the study of the initial settlement of America which deserved to be highlighted. The present paper reminds the two conflicting models that prevailed for the last twenty years of anthropological studies in America before browsing the newly accepted hypothesis about the origin of the first Amerindians as seen by its authors. Lastly, the paper evokes some areas of investigations which could furnish significant fallouts about the dynamics of the peopling of Americas in the future. 


\section{Introduction}

Since the $16^{\text {th }}$ century, the American continent has always gathered an uninterrupted interest in an anthropological and archaeological point of view. The origin of the ancestors of the present-day Native populations of America - namely Native Americans or Amerindians was mentioned in the very first times of exploration of the Americas by Jesuit Jose de Acosta (1589) and by French naturalist Georges-Louis Leclerc de Buffon (1749), completed in the twentieth century by the use of skeletal and biological investigations in extinct and extent Amerindians. Based on the dental [1], cranial [2], classical (i.e. red cell and protein) genetic systems [3, 4], prior anthropological studies about the dynamics of the initial peopling of America highlighted grades of allele frequencies as well as shared biological features between Amerindian and Asian populations, which strengthened Jose de Acosta's assumption which can be summarized as the incoming of the first Amerindians from Asia.

The first interdisciplinary scheme for the initial settlement of America has been proposed in the mid-1980s as elements of linguistics, dental morphology (28 crown and root traits) and genetics (serological genetic systems) [5]. [5]'s theory relied on a convergent classification of the Amerindian languages, dental traits and blood groups and protein genetic systems into three separate groups. Under their view, the present-day Amerindian populations originated from three distinct waves coming from Asia at the Pleistocene-Holocene transition $(\sim 12,000-10,000$ years before present, YBP), by way of the now-submerged Bering land bridge, Beringia, that could have emerged by a fall of the sea level of about $120 \mathrm{~m}$ from presently during the Last Glacial Maximum (LGM; 21,000-10,000 YBP) [6].

Briefly, [5] assumed that a first group of populations would have left Siberia, crossed Beringia and entered the Americas about 12,000 years ago to spread into most of the New World. These first Americans, also called Paleoindians, would have introduced the Amerind 
language family, nowadays widely spoken from North to South America (e.g. Cherokee, Maya or Quechua). Then, the Na-Dene speakers would have entered secondly to inhabit the interior of Alaska, the northern Pacific coast to the South-western states of USA, Arizona mainly (e.g. Navajo, Apache). Lastly the Eskimo-Aleut speakers would have arrived to occupy the Arctic periphery of America (e.g. Inuktitut). Interestingly, a first entrance into the Americas dated by 12,000 YBP found agreement in previous archaeological evidences from North America. Indeed, by the time of [5]'s hypothesis and years after, the fluted stone tool technology named "Clovis" and ${ }^{14} \mathrm{C}$ calibrated by about 11,000 YBP (11,050-10,800 ka BP [7]) was viewed as the oldest human manufacture of America. For the two last decades, [5]'s tripartite assumption remained thus the starting point for all subsequent works about the initial colonization of the Americas.

With the advent of improved methods of data exploration and treatment - increasing number of population genetic markers and longer DNA sequences, use of variance/covariance matrices, time divergence estimation, population structure analysis and Bayesian approach among others - abundant anthropological attempts have scrutinized the morphological and gene diversity found in past and present Amerindians. The main dataset encompasses skull and face remains (e.g. [8]) and two uniparentally inherited DNA: the mitochondrial DNA, or mtDNA, transmitted by women and the non-recombining portion of the Y-chromosome (NRY), only possessed by men (e.g. [9-11]). Later, additional information were provided by HLA genes [12, 13], the $\mathrm{X}$ and autosome chromosomes [14, 15] completed with archaeological evidences from North, Central and South America, and microbiology studies of bacteria Helicobacter pylori [16] and intestinal parasites (i.e. helminths - [17]); living forms that co-migrated with the human populations. As expected, undoubtedly clustering of the Amerindian to the Asian populations was found together with an unanimous challenge of [5]'s assumption putting forward a) a plausible earlier colonization than 12,000 YBP in 
agreement with the recognition of a pre-Clovis occupation (e.g. Paisley Cave, Cactus Hill, Valsequillo, Taima Taima, Monte Verde, Pedra Furada - [18-21] and b) controversies about the delimitation of the Amerind/Na-Dene/Eskimo-Aleut linguistic phyla into exactly three distinct biological stocks.

\section{The craniometric/genetic discrepancy}

The first molecular studies using the maternally inherited DNA (mtDNA) revealed that past and present-day Native Americans belong to five major distinct phylogenetic groups designated haplogroups A, B, C, D, and X, also present in populations from Siberia and parts of Asia [22]. The four American A-D mtDNAs are spread amongst North, Central and South Amerindians belonging to either the Amerind, Na-Dene and Eskimo-Aleut linguistic family as defined by [5] while $\mathrm{X}$ is restricted to North Amerindians [23]. Relatedness comparisons have showed closer mtDNA genetic similarities amongst the Amerind, Na-Dene and EskimoAleut populations present than with any Mongolian and East Asian ethnic group while coalescence time estimates for the age of the autochtonous mtDNAs indicated a simultaneous occurrence for all five Amerindian female lineages (between 19 and 15,000 YBP - [24]). Hence, mtDNA data pointed towards a unique migratory event for all Amerind, Na-Dene and Eskimo-Aleut populations which would have brought all Amerindian founding lineages from Asia, probably before 18,000 YBP [25-27].

Noteworthy are the geographic distributions of the minor $\mathrm{X}$ maternal lineage exclusively in North Amerindians (Ojibwa, Navajo, Nuu-Chah-Nulth and Sioux populations) $[23,28]$ and the Clovis lithic culture, also exclusive to North America. Given that $\mathrm{X}$ represents $\sim 4 \%$ of the European mtDNAs [29] and the resemblance between Clovis and the Solutrean "bay leaf" industry (South-western Europe; 22,000-17,000 YBP), the possibility of 
an additional settlement of North America from Europe has risen [30]. Nevertheless, inadmissibility of a putative European ancestry for North Amerindians has commonly been accepted because of the wide 10,000-years chronological gap between the Clovis and Solutrean cultures, dental and many other morphological similarities between Native Americans and East Asians not Europeans, and finally recent studies of the mtDNA that clearly distinguished the European from the Natives American founding X lineage, namely $\mathrm{X} 2 \mathrm{a}[22,31]$.

For analogous heritability properties to the mtDNA, the NRY represents a very useful tool to trace back the male lineages of the human populations. Former studies of the initial peopling of America using the NRY reported in Amerindians the predominance of one lineage, Q, absent in any African, Asian or European populations [10, 32, 33]. The Amerindian-specific Q lineage is made of the ancestral $Q^{*}$ haplogroup, the Y-chromosome lineage that could actually reach America, which afterwards derived into the predominant Q1a3a* lineage, which then evolved very locally into the most derived haplogroup Q1a3a1, found in populations from the western part of South America (59\% of the Ticuna, Brazilian State of Amazonas, and $10 \%$ of the Wayuu, Guajira peninsula, Colombia - $[32,34,35])$. Q and especially its sublineage Q1a3a* represent the majority of the Amerindian Ychromosomes in North, Central and South America (up to $100 \%$ in many populations), belonging to either the Amerind, Na-Dene and Eskimo-Aleut linguistic family of [5]'s classification. Besides the Q lineage, [36] detected a second male founder, $\mathrm{C}^{*}$, a very sporadic Y-chromosome haplogroup found in Asian (Korean and Japanese) and Plains Native American populations of North America (Cheyenne and Keres).

Such distribution coupled with an average age of the ancestral $\mathrm{Q}^{*}$ haplogroup estimated by 15,000 YBP [35] fit with the model of a major migratory event into America circa 18,000-15,000 YBP, which is similar to what observed for the mtDNA [24]. Afterwards, 
minor gene flows would have occurred between the Northernmost Asian and American populations and introduced locally the $\mathrm{C}^{*}$ male haplogroup into the hinterland of North American (coalescence age for the Native American C* : 9,500-7,600 YBP [36]).

In addition to mtDNA and NRY genetic studies, the initial settlement of America has received an increased attention by researchers working with craniometrical data, especially since the turn of the 1990s and the full description of the earliest Amerindian cranial remains in North, Central and South America (reviewed in [37]). Chronologically, the available Amerindian cranial dataset dates back from modern times to 13,500 YBP [38] and so far, has been stored into two distinct boxes according to the morphology. Skulls dating from 13,500 YBP to 7,000 YBP fall within the range described in Southeast Asian specimens from approximately the same period (before 10,000 YBP, Late Pleistocene) as well as in to modern Australians aborigines and populations from Oceania. The morphology was thus designated as "Australo-Melanesian" and can be broadly depicted as robust and elongated. Since 7000 YBP, the pattern changes radically in America. The "Australo-Melanesian" morphology is suddenly replaced by slender, shorter and wider skulls, labelled as "Mongoloid" since they are similar to what observed from 10,000 YBP to present in Asia [39].

In this context, modern humans morphologically Australo-Melanesian-like could have departed from a common ancestor with Australians about 60,000 years ago in South-eastern Asia, then reached Northeast Asia [40] before entering the Americas around 14,000 YBP. Afterwards, by the turn of the Holocene (around 11,000 YBP), the "Mongoloid" morphology would have been fixed in northeast Asian populations before entering America later, ca. 8,000 years BP (see Fig. 9 in [41]). This model, known as the "two biological components" hypothesis, thus asserts that two human stocks have settled successively the American continent, implying that more than one migration wave could have occurred. 
To resume, both craniometry and genetics challenged the three-wave hypothesis of [5] but each has led to the formulation of a distinct model for the initial colonization of America depending on how the Amerindian biological variability has been divided : a) the migratory hypothesis, i.e. the biological variation among Amerindians was the result of a variable number of migratory waves made of populations of different biological stocks that entered successively the continent, as suggested by morphological data; and b) the local diversification hypothesis, under which all Amerindians would be descended from a unique event with high level of gene diversity followed by local random (genetic drift) and probably non-random (selection) differentiation processes that could explain the biological diversification amongst North, Central and South Amerindians, as supported by genetic evidences.

\section{Reconciling data under a consensus model}

Lately, the result of two decades of discordance between the genetic and craniometrical scholars for the early settlement of America has led the anthropologists to set about two main aspects of the studies carried out so far: first, a re-appreciation of the Amerindian biological variability in the light of advanced methods in molecular biology, craniometry and statistics [24, 37, 42], and second, detachment from the nomenclature employed in craniometry in order to discuss objectively the amount of variability observed at the morphological level [37].

The first turning point came from genetics and the revelation of the existence of specific mutations in the entire Amerindian maternal gene stock absent in any Asian populations [27, 43]. If so, the geographically-restricted polymorphisms must have accumulated prior the expansion of the first Amerindians throughout the New World but 
outside of the main Asian landmass. In addition, paleoecological and archaeological researches have demonstrated the existence of a human standstill in the Beringian peripheries during the Last Glacial Maximum ( 21,000-11,000 YBP) due to favorable climatic conditions and abundant resources for cynegenetic activities [44-46]. Consequently, Beringia appeared as the best candidate for the place of maturation of the specific Amerindian mtDNA polymorphisms. By the way, Bayesian simulations performed with A2, B2, C, D1 and X2a complete mtDNA genomes from Native Americans agreed with an occurrence of the Amerindian founding mutations coetaneous of the Beringian occupation, [43]. Therefore, while former "Out of Asia" models (e.g. [5]'s and the "two-components") regarded Beringia merely as a footbridge towards America - North-eastern Siberian populations would have "jumped" or "run" from one continent to the other - the settlement of America could be viewed as an "Out of Beringia" or "Beringian Incubation" instead, as named by [26] and [42] respectively, under which Asian-descendant populations could have settled long enough to differentiate by mutation before expanding into America [24, 26, 42].

The other turning point was pointed out by [37] who highlighted that the disagreement between craniometrical and molecular inferences could rely on data themselves which could not express the same level of variance because they differ in mutation rate, environmental influence $[47,48]$ and demographical information due to their respective mechanisms of inheritance (mtDNA and Y-chromosome population effective size equals one fourth of the autosome one). Overall, the same author emphasized two main criticisms in the morphometric approach which could have been responsible for the disagreement that prevailed so far. First, crania were commonly examined using classical morphological methods which basically measures segments or linear distances between main landmarks (e.g. length, width and height of the neurocrania, face and facial cavities). The use of such methods disregards the shape of the skulls that is the actual geometric information of the curves of the vault, usually measured 
using semi-landmarks and depicted onto a grid deformation. Though widely employed, the use of the linear measurement methods turned out to not account accurately for the amount of within-sample and within-group variance contained by such a structure that is a calvarium. Second, the specimens have been prejudiced to belong to segregated "boxes" such as "Australo-Melanesian" or "Mongoloid", which is too reductive as far as the notion of variance is concerned.

Consequently, taking especially into consideration the cranial geometric shape and discounting the compartmented system of classification, re-comparisons of AustraloMelanesian-like and Mongoloid-like morphologies in America have revealed that most Amerindian skull morphs were actually distributed on a single continuous spectrum of variation whose extremes correspond to the past "Australo-Melanesian" and "Mongoloid" designations [37]. In other words, the Amerindian cranial variation could be represented by one continuum array of shapes whose limits are not easily to set and given that, the past "Australo-Melanesian" and "Mongoloid" labels should be used with care and the "twocomponent model" for the peopling of America might be partially revised.

In order to explain harmoniously the craniometrical and genetic variability found in past and present Native American populations, a consensus model of the first colonization of the continent has been designed [37, 42]. Figure 1 sum up how the initial peopling of America could have occurred in time and space. It is important to keep in mind that Beringia is likely to have been inhabited from 21,000 to 7000 YBP and meanwhile a population flow may have constantly expand into America.

The model assumes that during the Late Pleistocene (before 26,000 YBP $-18,000$ YBP), Asian populations were being migrated towards the north-eastern part of Siberia, carrying a broadly non-derived cranial morphology (formerly "Australo-Melanesian") and at least the Eurasian A-D, X mtDNAs and $\mathrm{P}^{*}$ Y-chromosomes, ancestral to Q. By this period, a 
decrease of the sea level made the shoal between present-day Alaska and eastern Siberia emerged, shaping a land bridge of roughly $1,500 \mathrm{~km}$ north to south at its greatest extent. Archaeological and paleoclimatic evidences from this period pointed to a substantial human settlement as an extension of the Siberian populations. Nevertheless, ice shields were covering most of North America so that human progression was unlikely to occur farther than present-day Alaska. Therefore, at this very step, Beringia was inhabited by populations with genetic and morphological components of Asian origin, and time divergence estimations from genetics suggested that they started maturing to constitute the genetic stock presently found in Amerindians.

Then, between 18,000 YBP and the end of the Pleistocene (12,000 YBP), global warming led to a sea level rise and thus a reduction of the Beringian plain. Despite the topping of North America landmass by glaciers, the beginning of the ice melting opened some coastal routes and probably continental ice-free corridors [44]. Consequently, Beringian populations could expand eastward to give rise to the first Americans. The first human settlement of America may have begun in these dates. The presence of the non-derived cranial morphology in the western peninsula of Mexico plus numerous pre-Clovis sites in the northwestern coast of North America and patterns of diffusion of the gene diversity agree with a diffusion of the first Amerindians along the Pacific rim of America [14, 44, 46, 49, 50]. At the end of this step, by 12,000 YBP, humans were certainly present all over the continent as attested by numerous occupation sites in North, South-West and South-East America [20]. Specialized A2, B2, C1, D1 and X2a plus minor mtDNAs (e.g. C4c - [50]), the Q* NRY founding lineage and an ancestral craniofacial morphology (i.e. robust and elongated) could constitute the main biological variability of these populations.

Lastly, the Holocene (12,000 YBP to present) is regarded in northeast Asian and remaining Beringian populations as the period of a significant biological specialization with 
the emergence and fixation of the derived craniofacial morphology. Under the view of an ongoing population expansion into America, the newly acquired phenotypic traits would have been diffused by the last Beringian populations. In Native Americans, the male Q lineage evolved into Q1a3a* followed by a very local appearance of the Q1a3a1 sub-haplogroup [34] by $8,000-7,000 \mathrm{YBP}$, while some mtDNAs may have known an ongoing evolution into minor lineages. In the peri-arctic regions, the newly Arctic Amerindians and the neighbouring northeastern Asians may not have been totally cut off once the Americas conquered but on the contrary significant back and forth gene flows would have allegedly occurred. Clues are the presence of the Siberian craniofacial pattern (i.e. facial flatness and zygomatic projection) in Eskimo populations (reviewed in [37]), two minor mtDNA sub-clades derived from the Amerindian A2 and $\mathrm{C} 1$ described in two inner Siberian ethnic groups near the Yenissei river, the Evenk and Selkup [42], plus numerous archaeological evidences [51]. Moreover, in a scenario labelled as "Recurrent Gene Flow" designed from Bayesian simulations [52], most the Amerindian genetic picture observed for the nuclear DNA would match with an initial peopling of America from Beringia permeable in the northernmost latitudes.

Finally, at the demographic level, though an effective population expansion is widely accepted given that the Native American maternal lineages differentiated in a relative short time interval (between 19 and 15,000 YBP [24]), many clues indicated that the initial peopling of America was associated with an early founder effect due to a genetic bottleneck or population constriction while migrating, whose amplitude ranges from severe (i.e. less than 100 effective founders - $[52,53])$ to moderate [54]. This is for instance illustrated by the predominance of several private alleles or haplotypes in Amerindians such as the male Q lineage [10], the prevalence of the O blood group (up to 100\%) in Central and South Amerindians which is unique at the word scale [55], and the ubiquitous 9RA allele at locus D9S1120 [56]. 


\section{Is the peopling of the Americas resolved anyway?}

Two decades of exhaustive researches from physical and biological anthropologists coupled with detailed paleoglacial and archaeological evidences from the Beringia area for the Pleistocene-Holocene transition as well as revisions of the craniofacial systematics shed bright light onto the patterns of the early expansion of Native Americans. But as they brought the initial peopling of America out in the open, several aspects remain ill-known and below are briefly presented those of primary importance.

First, though Late Pleistocene archaeological evidences in America and gene diversity distribution pointed towards population diffusion along the Pacific coast, little is known about the longitudinal spread of the first Native Americans in North and South America. In South America this is very problematic since a genetic heterogeneity has usually been described between Western and Eastern South Amerindians but one could not figure out if the Andes/Amazonia genetic disparity has been shaped by distinct demography and gene flow levels or peopling events after crossing the Panama Isthmus [14, 57, 58].

As far as North America is concerned, the occurrence of a homogeneous cultural layer represented by the Clovis and subsequent lithic industries together with the $\mathrm{ABO}^{*} \mathrm{~A}$ and $\mathrm{B}$ phenotypes, $\mathrm{X} 2 \mathrm{a}$ mtDNAs and $\mathrm{C}^{*}$ Y-chromosomes $[23,36]$ absent in any populations southward a line starting at the Sonora desert towards the Rio Grande river could indicate different patterns of peopling dynamics for North Native Americans. Indeed, the restricted occurrence of the mtDNA X2a and Y-chromosome $\mathrm{C}^{*}$ in Great Lakes North Amerindians was either explained as the result of simultaneous but independent migratory waves into America (a coastal and a hinterland $[59,60]$ ) or as an unaccomplished migration towards the South. Indeed, the probability of survival of an allele during a migration depends partially on 
its proximity to the migration front [61], hence $\mathrm{X} 2 \mathrm{a}$ and $\mathrm{C}^{*}$ may have belong to a unique coastal diffusion but located on its edge and in these conditions, could have missed the wave towards Central and South America [24]. Another and not exclusive explanation could be the occurrence of a major cultural/genetic barrier that could have divided the continent into two entities. We for instance know the apparition of biological barriers since the early Holocene in Baja California (Sonora desert precisely) and Tierra de Fuego (Magellan Strait), as showed by the persistence of the "Australo-Melanesian" morphology beyond the 7,000-YBP threshold in those two remote areas isolated by ca. 8,000 YBP by climatic changes $[49,62,63]$.

Anyway the two above-listed patterns for North and South Amerindians will certainly remain unresolved if still using the unbalanced geographic covering of the samples as considered in the genetic studies led so far. Noteworthy is the paucity for the North America landmass, Amazonian savannah and rainforest (e.g. [14, 64]) with regards to the high density of Central and Andean samples but fortunately for some of them the inclusion of a more representative sampling is being carried out.

Second, favorable taphonomic conditions for the conservation of the DNA and improved paleogenetic techniques allowed the examination of the mtDNA gene pool in extinct populations from the northwestern coast, Andes, Amazonia and southern cone of America (e.g. [65]). Samples range from 8,000 YBP to the nineteenth century but most of them are representative of the derived craniofacial phenotype and so that little is known about the mtDNA gene pool carried by the very first inhabitants of the Americas of "AustraloMelanesian-like" craniofacial morphology besides they belong to the A-D maternal founding lineages [66]. Another interesting paleogenetic feature for Native Americans is the peculiarity found in two mid-Holocene ( $5000 \mathrm{YBP})$ individuals from British Columbia, since they are likely to belong the mtDNA haplogroup M, a common type found in East Asia but never reported in ancient or living indigenous populations of America [67] (Bravi CM, personnal 
communication). Hence, multiplication of ancient DNA (aDNA) attempts should establish in the future a better knowledge of the past gene pool that entered the Americas.

In addition, the American landmass gathers numerous and contrasted environmental conditions especially for the intertropical region where dry highlands are flanking humid lowlands. Though the settlement of America is a very recent event in the story of Homo sapiens sapiens, selective pressure could not be disregarded if one would explain accurately the patterns of phenotypic variability described from North to South America. For instance, as far as the predominance of the $\mathrm{O}$ blood group is concerned, hookworm and roundworm parasites on male gametes could have acted concomitantly with an early founder effect for the elimination of the $\mathrm{ABO} * \mathrm{~A}$ and $\mathrm{ABO} * \mathrm{~B}$ phenotypes in South Amerindians. The process would involve a natural over-production of A-like and B-like antibodies due to the presence of A-like and B-like antigens onto the parasite. The antibodies could interact with a spermatozoid wearing A or B antigens in the female genital tractus if she is carrier of the Secretor gene [68]. Since many other biological/environmental interactions have largely taken place in Amerindians[69] and the ongoing development of high-resolution techniques in molecular biology such as DNA sequencing and genome-wide screening [14, 64] more investigations are justified in this sense in the future.

Lastly, maybe the emergence and fixation of the derived cranial traits observed in North-eastern Asians and Amerindians from 10,000 YBP to present is one of the most enigmatic patterns of the peopling of America. One can interestingly remind that mastication could act in the craniofacial variation among recent humans [70] and that the morphological evolution from ancestral to derived traits in Asians and Amerindians coincide with at a major climatic ecological change, the Pleistocene/Holocene transition. Hence, the study of the phenotypic evolution of the first modern humans in Asia under genetic, environmental and functional forces is of major importance for an near accomplished understanding of the 
dynamics of the initial settlement of America and even of the evolutionary history of Homo sapiens sapiens, a topic that is being carried out $[70,71]$.

\section{Conclusion}

For that last twenty years the Natives American populations has been regarded by genetics and craniometry as respectively the results of a unique event followed by local differentiation mechanisms or two successive entrances of distinct biological stocks. Revisions of the Amerindian craniofacial diversity and description methods led the biological anthropologists to adopt a new position about the morphological variability observed in America. Consequently, the data could now found agreement if considered in a modified model under which the dynamics of the peopling of America focus on the Beringian region. In practical terms, the plain between Asia and America that emerged at the Late Pleistocene would have had a central role of genetic differentiation, then craniofacial evolution under Asian populations' influence. The migration towards America could have started from 18,000 YBP and taken place for almost 10,000 years. In the meantime, permanent gene flows were likely to occur amongst the inhabitants of the Siberian and American Arctic. Finally, several topics for thoughts came out from the study of the settlement of America, such as the lack of a fairly representative sampling of all parts of the Americas, the Amerindian archaeological and biological discontinuity from $\sim 30^{\circ} \mathrm{N}$ and the putative role of the Sonora desert as a cap in gene and cultural exchanges during the Holocene, and the contribution of the environment onto the Native American phenotypes. 


\section{Acknowledgement}

The present paper was envisaged in the context of the Programme Interdisciplinaire Amazonie (Analyse, modélisation et ingénierie des systèmes amazoniens), Laboratoire d'Anthropologie Moléculaire et Imagerie de Synthèse, FRE 2960 CNRS, Université Paul Sabatier.

\section{References}

[1] C.G. Turner, Dental evidence for the peopling of the Americas, in: R.J. Shulter (Ed.), Early man in the New World, Sage, Beverly Hills, 1983, pp. 147-157.

[2] W. Neves, H. Pucciarelli, Extra continental biological relationships of early South American human remains: a multivariate analysis, Cienc Cult 41 (1989) 566-575.

[3] M. Layrisse, J. Wilbert, Absence of the Diego antigen, a genetic characteristic of early immigrants to South America, Science 134 (1961) 1077-1078.

[4] L.L. Cavalli-Sforza, P. Menozzi, A. Piazza, The history and geography of human genes, Princeton University Press, Princeton, 1994.

[5] J.H. Greenberg, C.G. Turner, S.L. Zegura, The settlement of the Americas: a comparison of the linguistic, dental, and genetic evidence, Curr Anthropolo 27 (1986) 477-497.

[6] A.V. Alfimov, D.I. Berman, Beringian climate during the Late Pleistocene and Holocene, Quaternary Sci Rev 20 (2001) 127-134.

[7] M.R. Waters, T.W. Stafford, Jr., Redefining the age of Clovis: implications for the peopling of the Americas, Science 315 (2007) 1122-1126.

[8] R. Gonzalez-Jose, W. Neves, M.M. Lahr, S. Gonzalez, H. Pucciarelli, M. Hernandez 
Martinez, G. Correal, Late Pleistocene/Holocene craniofacial morphology in Mesoamerican Paleoindians: implications for the peopling of the New World, Am J Phys Anthropol 128 (2005) 772-780.

[9] T.G. Schurr, S.W. Ballinger, Y.Y. Gan, J.A. Hodge, D.A. Merriwether, D.N. Lawrence, W.C. Knowler, K.M. Weiss, D.C. Wallace, Amerindian mitochondrial DNAs have rare Asian mutations at high frequencies, suggesting they derived from four primary maternal lineages, Am J Hum Genet 46 (1990) 613-623.

[10] S.D. Pena, F.R. Santos, N.O. Bianchi, C.M. Bravi, F.R. Carnese, F. Rothhammer, T. Gerelsaikhan, B. Munkhtuja, T. Oyunsuren, A major founder Y-chromosome haplotype in Amerindians, Nat Genet 11 (1995) 15-16.

[11] T.G. Schurr, S.T. Sherry, Mitochondrial DNA and Y chromosome diversity and the peopling of the Americas: evolutionary and demographic evidence, Am J Hum Biol 16 (2004) 420-439.

[12] A. Arnaiz-Villena, G. Vargas-Alarcon, J. Granados, E. Gomez-Casado, J. Longas, M. Gonzales-Hevilla, J. Zuniga, N. Salgado, G. Hernandez-Pacheco, J. Guillen, J. Martinez-Laso, HLA genes in Mexican Mazatecans, the peopling of the Americas and the uniqueness of Amerindians, Tissue antigens 56 (2000) 405-416.

[13] J. Moscoso, M.H. Crawford, J.L. Vicario, M. Zlojutro, J.I. Serrano-Vela, R. Reguera, A. Arnaiz-Villena, HLA genes of Aleutian Islanders living between Alaska (USA) and Kamchatka (Russia) suggest a possible southern Siberia origin, Mol Immunol 45 (2008) 1018-1026.

[14] S. Wang, C.M. Lewis, M. Jakobsson, S. Ramachandran, N. Ray, G. Bedoya, W. Rojas, M.V. Parra, J.A. Molina, C. Gallo, G. Mazzotti, G. Poletti, K. Hill, A.M. Hurtado, D. Labuda, W. Klitz, R. Barrantes, M.C. Bortolini, F.M. Salzano, M.L. Petzl-Erler, L.T. Tsuneto, E. Llop, F. Rothhammer, L. Excoffier, M.W. Feldman, N.A. Rosenberg, A. 
Ruiz-Linares, Genetic variation and population structure in native Americans, PLoS genetics 3 (2007) e185.

[15] S. Bourgeois, V. Yotova, S. Wang, S. Bourtoumieu, C. Moreau, R. Michalski, J.P. Moisan, K. Hill, A.M. Hurtado, A. Ruiz-Linares, D. Labuda, X-chromosome lineages and the settlement of the Americas, Am J Phys Anthropol 140 (2009) 417-428.

[16] C. Ghose, G.I. Perez-Perez, M.G. Dominguez-Bello, D.T. Pride, C.M. Bravi, M.J. Blaser, East Asian genotypes of Helicobacter pylori strains in Amerindians provide evidence for its ancient human carriage, Proc Natl Acad Sci U S A 99 (2002) 1510715111

[17] A. Araujo, K.J. Reinhard, L.F. Ferreira, S.L. Gardner, Parasites as probes for prehistoric human migrations?, Trends in parasitology 24 (2008) 112-115.

[18] P.G. Bahn, Archaeology. 50,000-year-old Americans of Pedra Furada, Nature 362 (1993) 114-115.

[19] T.D. Dillehay, The Late Pleistocene Cultures of South America, Evol Anthropol 7 (1999) 206-216.

[20] S.J. Fiedel, The peopling of the New World: present evidence, new theories, and future directions, J Archaeol Res 8 (2000) 39-103.

[21] A. Vilhena-Vialou, Pré-história do Mato Grosso, vol. I - Santa Elina, EDUSP, São Paulo, 2006, p. 254.

[22] H.J. Bandelt, C. Herrnstadt, Y.G. Yao, Q.P. Kong, T. Kivisild, C. Rengo, R. Scozzari, M. Richards, R. Villems, V. Macaulay, N. Howell, A. Torroni, Y.P. Zhang, Identification of Native American founder mtDNAs through the analysis of complete mtDNA sequences: some caveats, Ann Hum Genet 67 (2003) 512-524.

[23] C.L. Dornelles, S.L. Bonatto, L.B. De Freitas, F.M. Salzano, Is haplogroup X present in extant South American Indians?, Am J Phys Anthropol 127 (2005) 439-448. 
[24] N.J. Fagundes, R. Kanitz, R. Eckert, A.C. Valls, M.R. Bogo, F.M. Salzano, D.G. Smith, W.A. Silva, Jr., M.A. Zago, A.K. Ribeiro-dos-Santos, S.E. Santos, M.L. PetzlErler, S.L. Bonatto, Mitochondrial population genomics supports a single pre-Clovis origin with a coastal route for the peopling of the Americas, Am J Hum Genet 82 (2008) 583-592.

[25] P. Forster, R. Harding, A. Torroni, H.J. Bandelt, Origin and evolution of Native American mtDNA variation: a reappraisal, Am J Hum Genet 59 (1996) 935-945.

[26] S.L. Bonatto, F.M. Salzano, A single and early migration for the peopling of the Americas supported by mitochondrial DNA sequence data, Proc Natl Acad Sci U S A 94 (1997) 1866-1871.

[27] D.A. Merriwether, F. Rothhammer, R.E. Ferrell, Distribution of the four founding lineage haplotypes in Native Americans suggests a single wave of migration for the New World, Am J Phys Anthropol 98 (1995) 411-430.

[28] M.D. Brown, S.H. Hosseini, A. Torroni, H.J. Bandelt, J.C. Allen, T.G. Schurr, R. Scozzari, F. Cruciani, D.C. Wallace, mtDNA haplogroup X: An ancient link between Europe/Western Asia and North America?, Am J Hum Genet 63 (1998) 1852-1861.

[29] A. Torroni, K. Huoponen, P. Francalacci, M. Petrozzi, L. Morelli, R. Scozzari, D. Obinu, M.L. Savontaus, D.C. Wallace, Classification of European mtDNAs from an analysis of three European populations, Genetics 144 (1996) 1835-1850.

[30] B. Bradley, D. Stanford, The North Atlantic ice-edge corridor: a possible Palaelithic route to the New Word, Word Archaeol 36 (2004) 459-478.

[31] R.S. Malhi, D.G. Smith, Brief communication: Haplogroup X confirmed in prehistoric North America, Am J Phys Anthropol 119 (2002) 84-86.

[32] A. Ruiz-Linares, D. Ortiz-Barrientos, M. Figueroa, N. Mesa, J.G. Munera, G. Bedoya, I.D. Velez, L.F. Garcia, A. Perez-Lezaun, J. Bertranpetit, M.W. Feldman, D.B. 
Goldstein, Microsatellites provide evidence for $\mathrm{Y}$ chromosome diversity among the founders of the New World, Proc Natl Acad Sci U S A 96 (1999) 6312-6317.

[33] P.A. Underhill, L. Jin, R. Zemans, P.J. Oefner, L.L. Cavalli-Sforza, A pre-Columbian Y chromosome-specific transition and its implications for human evolutionary history, Proc Natl Acad Sci U S A 93 (1996) 196-200.

[34] M.C. Bortolini, F.M. Salzano, M.G. Thomas, S. Stuart, S.P. Nasanen, C.H. Bau, M.H. Hutz, Z. Layrisse, M.L. Petzl-Erler, L.T. Tsuneto, K. Hill, A.M. Hurtado, D. Castrode-Guerra, M.M. Torres, H. Groot, R. Michalski, P. Nymadawa, G. Bedoya, N. Bradman, D. Labuda, A. Ruiz-Linares, Y-chromosome evidence for differing ancient demographic histories in the Americas, Am J Hum Genet 73 (2003) 524-539.

[35] M. Seielstad, N. Yuldasheva, N. Singh, P. Underhill, P. Oefner, P. Shen, R.S. Wells, A novel Y-chromosome variant puts an upper limit on the timing of first entry into the Americas, Am J Hum Genet 73 (2003) 700-705.

[36] A.W. Bergen, C.Y. Wang, J. Tsai, K. Jefferson, C. Dey, K.D. Smith, S.C. Park, S.J. Tsai, D. Goldman, An Asian-Native American paternal lineage identified by RPS4Y resequencing and by microsatellite haplotyping, Ann Hum Genet 63 (1999) 63-80.

[37] R. Gonzalez-Jose, M.C. Bortolini, F.R. Santos, S.L. Bonatto, The peopling of America: craniofacial shape variation on a continental scale and its interpretation from an interdisciplinary view, Am J Phys Anthropol 137 (2008) 175-187.

[38] W.A. Neves, M. Hubbe, Cranial morphology of early Americans from Lagoa Santa, Brazil: implications for the settlement of the New World, Proc Natl Acad Sci U S A 102 (2005) 18309-18314.

[39] M.M. Lahr, The evolution of modern human diversity: a study of cranial variation, Cambridge University Press, Cambridge, 1996.

[40] W. Neves, H. Pucciarelli, The Zhoukoudian Upper Cave skull 101 as seen from the 
Americans, J Hum Evol 34 (1998) 219-222.

[41] W.A. Neves, A. Prous, R. Gonzalez-Jose, R. Kipnis, J. Powell, Early Holocene human skeletal remains from Santana do Riacho, Brazil: implications for the settlement of the New World, J Hum Evol 45 (2003) 19-42.

[42] E. Tamm, T. Kivisild, M. Reidla, M. Metspalu, D.G. Smith, C.J. Mulligan, C.M. Bravi, O. Rickards, C. Martinez-Labarga, E.K. Khusnutdinova, S.A. Fedorova, M.V. Golubenko, V.A. Stepanov, M.A. Gubina, S.I. Zhadanov, L.P. Ossipova, L. Damba, M.I. Voevoda, J.E. Dipierri, R. Villems, R.S. Malhi, Beringian standstill and spread of Native American founders, PloS one 2 (2007) e829.

[43] N.J. Fagundes, R. Kanitz, S.L. Bonatto, A reevaluation of the Native American mtDNA genome diversity and its bearing on the models of early colonization of Beringia, PloS one 3 (2008) e3157.

[44] E.J. Dixon, Human colonization of the Americas: timing, technology and process, Quaternary Sci Rev 20 (2001) 277-299.

[45] J.F. Hoffecker, W.R. Powers, T. Goebel, The colonization of beringia and the peopling of the new world, Science 259 (1993) 46-53.

[46] T. Goebel, M.R. Waters, D.H. O'Rourke, The late Pleistocene dispersal of modern humans in the Americas, Science 319 (2008) 1497-1502.

[47] J.H. Relethford, Craniometric variation among modern human populations, Am J Phys Anthropol 95 (1994) 53-62.

[48] D. Mishmar, E. Ruiz-Pesini, P. Golik, V. Macaulay, A.G. Clark, S. Hosseini, M. Brandon, K. Easley, E. Chen, M.D. Brown, R.I. Sukernik, A. Olckers, D.C. Wallace, Natural selection shaped regional mtDNA variation in humans, Proc Natl Acad Sci U S A $100(2003)$ 171-176.

[49] R. Gonzalez-Jose, A. Gonzalez-Martin, M. Hernandez, H.M. Pucciarelli, M. Sardi, A. 
Rosales, S. Van Der Molen, Craniometric evidence for Palaeoamerican survival in Baja California, Nature 425 (2003) 62-65.

[50] N.N. Yang, S. Mazieres, C. Bravi, N. Ray, S. Wang, M.W. Burley, G. Bedoya, W. Rojas, M.V. Parra, J.A. Molina, C. Gallo, G. Poletti, K. Hill, A.M. Hurtado, M.L. Petzl-Erler, L.T. Tsuneto, W. Klitz, R. Barrantes, E. Llop, F. Rothhammer, D. Labuda, F.M. Salzano, M.C. Bortolini, L. Excoffier, J.M. Dugoujon, A. Ruiz-Linares, Contrasting patterns of nuclear and mtDNA diversity in Native American populations, Ann Hum Genet 74 (2010) 525-538.

[51] T. Goebel, M.R. Waters, M. Dikova, The archaeology of Ushki Lake, Kamchatka, and the Pleistocene peopling of the Americas, Science 301 (2003) 501-505.

[52] N. Ray, D. Wegmann, N.J. Fagundes, S. Wang, A. Ruiz-Linares, L. Excoffier, A statistical evaluation of models for the initial settlement of the american continent emphasizes the importance of gene flow with Asia, Mol Biol Evol 27 (2010) 337-345.

[53] J. Hey, On the number of New World founders: a population genetic portrait of the peopling of the Americas, PLoS biology 3 (2005) e193.

[54] J. Battilana, N.J. Fagundes, A.H. Heller, A. Goldani, L.B. Freitas, E. Tarazona-Santos, B. Munkhbat, N. Munkhtuvshin, M. Krylov, L. Benevolenskaia, F.C. Arnett, M.A. Batzer, P.L. Deininger, F.M. Salzano, S.L. Bonatto, Alu insertion polymorphisms in Native Americans and related Asian populations, Ann Hum Biol 33 (2006) 142-160.

[55] A.E. Mourant, A.C. Kopec, K. Domaniewska-Sobczak, The ABO blood groups: comprehensive tables and maps of world distribution, Blackwell Scientific Publications, Oxford, 1958.

[56] K.B. Schroeder, T.G. Schurr, J.C. Long, N.A. Rosenberg, M.H. Crawford, L.A. Tarskaia, L.P. Osipova, S.I. Zhadanov, D.G. Smith, A private allele ubiquitous in the Americas, Biol Lett 3 (2007) 218-223. 
[57] E. Tarazona-Santos, D.R. Carvalho-Silva, D. Pettener, D. Luiselli, G.F. De Stefano, C.M. Labarga, O. Rickards, C. Tyler-Smith, S.D. Pena, F.R. Santos, Genetic differentiation in South Amerindians is related to environmental and cultural diversity: evidence from the Y chromosome, Am J Hum Genet 68 (2001) 1485-1496.

[58] F. Rothhammer, T.D. Dillehay, The late Pleistocene colonization of South America: an interdisciplinary perspective, Ann Hum Genet 73 (2009) 540-549.

[59] U.A. Perego, A. Achilli, N. Angerhofer, M. Accetturo, M. Pala, A. Olivieri, B.H. Kashani, K.H. Ritchie, R. Scozzari, Q.P. Kong, N.M. Myres, A. Salas, O. Semino, H.J. Bandelt, S.R. Woodward, A. Torroni, Distinctive Paleo-Indian migration routes from Beringia marked by two rare mtDNA haplogroups, Curr Biol 19 (2009) 1-8.

[60] D.H. O'Rourke, Human migrations: the two roads taken, Curr Biol 19 (2009) R203205.

[61] S. Klopfstein, M. Currat, L. Excoffier, The fate of mutations surfing on the wave of a range expansion, Mol Biol Evol 23 (2006) 482-490.

[62] R. Gonzalez Jose, C. Garcia-Moro, S. Dahinten, M. Hernandez, Origin of FueguianPatagonians: an approach to population history and structure using $\mathrm{R}$ matrix and matrix permutation methods, Am J Hum Biol 14 (2002) 308-320.

[63] S.I. Perez, V. Bernal, P.N. Gonzalez, Morphological differentiation of aboriginal human populations from Tierra del Fuego (Patagonia): implications for South American peopling, Am J Phys Anthropol 133 (2007) 1067-1079.

[64] M. Jakobsson, S.W. Scholz, P. Scheet, J.R. Gibbs, J.M. VanLiere, H.C. Fung, Z.A. Szpiech, J.H. Degnan, K. Wang, R. Guerreiro, J.M. Bras, J.C. Schymick, D.G. Hernandez, B.J. Traynor, J. Simon-Sanchez, M. Matarin, A. Britton, J. van de Leemput, I. Rafferty, M. Bucan, H.M. Cann, J.A. Hardy, N.A. Rosenberg, A.B. Singleton, Genotype, haplotype and copy-number variation in worldwide human 
populations, Nature 451 (2008) 998-1003.

[65] M.L. Moraga, P. Rocco, J.F. Miquel, F. Nervi, E. Llop, R. Chakraborty, F. Rothhammer, P. Carvallo, Mitochondrial DNA polymorphisms in Chilean aboriginal populations: implications for the peopling of the southern cone of the continent, Am J Phys Anthropol 113 (2000) 19-29.

[66] S.I. Perez, V. Bernal, P.N. Gonzalez, M. Sardi, G.G. Politis, Discrepancy between cranial and DNA data of early Americans: implications for American peopling, PLoS One 4 (2009) e5746.

[67] R.S. Malhi, B.M. Kemp, J. Eshleman, J. Cybulski, D.G. Smith, S. Cousins, H. Harry, Haplogroup M Discovered in Prehistoric North America, J Archaeol Sci 34 (2007) 642-648.

[68] J. Ruffié, J. Ducos, G. Larrouy, Y. Marty, E. Ohayon, P. Fernet, Sur la fréquence élevée des anticorps anti-A et anti-B de haut titre dans les tribus amérindiennes. Rôle possible comme facteur sélectif. , C. R. Acad. Sc. Paris 264 (1967) 1792-1795.

[69] F.M. Salzano, S.M. Callegari-Jacques, South American Indians: A Case Study In Evolution, Clarendon Press, Oxford, 1988.

[70] C. Paschetta, S. de Azevedo, L. Castillo, N. Martinez-Abadias, M. Hernandez, D.E. Lieberman, R. Gonzalez-Jose, The influence of masticatory loading on craniofacial morphology: A test case across technological transitions in the Ohio valley, Am J Phys Anthropol 141 (2010) 297-314.

[71] Y. Coppens, D. Tseveendorj, F. Demeter, T. Turbat, P.H. Giscard Discovery of an archaic Homo sapiens skullcap in Northeast Mongolia, Comptes Rendus Palévol 7 (2008) 51-60. 
Figure 1. Basic scheme of the initial peopling of Beringia and America based on Fig.5 of [37]. The shaded areas represent the location of mountain glaciers and the black outlines the approximate Beringian shoreline [6]. Craniofacial variability is represented by a grey scale from dark ("Australo-Melanesian") to bright ("Mongoloid"). Size of the ellipse is a relative representation of the reduction or expansion of the population effective size. Lineages are defined by font types (regular: mtDNA; italic: Y-chromosome, bold: new lineage). The dotted arrow stands for population migration and/or gene flows. 